\title{
Identification of Aluminum Species in an Aluminum-accumulating Plant, Hydrangea (Hydrangea macrophylla), by Electrospray Ionization Mass Spectrometry
}

\author{
Hiroki HotTa, ${ }^{* \dagger}$ Qiang Wang, ${ }^{*}$ Mioko Fukuda, ${ }^{*}$ Shoichi Aizawa, ${ }^{*}$ Tomonari Umemura, ** \\ Kazutoshi SeKIZAwa,* and Kin-ichi TsunOdA*
}

*Department of Chemistry and Chemical Biology, Gunma University, Kiryu 376-8515, Japan

**Department of Applied Chemistry, Graduate School of Engineering, Nagoya University, Furo, Chikusa, Nagoya 464-8603, Japan

\begin{abstract}
The use of electrospray ionization mass spectrometry (ESI-MS) in negative ion mode was investigated as a direct probe for identifying Al species in Al-accumulating hydrangea (Hydrangea macrophylla) samples. Cell sap solutions of hydrangea leaves were purified using Sephadex G-10 liquid chromatography and each fraction was analyzed using ESIMS and ESI-MS/MS to identify Al species. In hydrangea leaves, a 1:1 Al-citrate complex was found as $\left[\mathrm{AlH}_{-1} \mathrm{cit}^{-}{ }^{-}\left(\mathrm{m}^{-} \mathrm{z}\right.\right.$ 215), where $\mathrm{H}_{3}$ cit denotes citric acid. This result is consistent with that of Ma et al. who used ${ }^{27} \mathrm{Al}-\mathrm{NMR}$.
\end{abstract}

(Received February 15, 2008; Accepted April 18, 2008; Published June 10, 2008)

\section{Introduction}

Aluminum is widely distributed in nature, but its roles in biological and environmental systems remain unclear., ${ }^{1,2}$ In particular, the biotoxicity of $\mathrm{Al}$ is largely dependent on its chemical form; therefore, its speciation analysis has been an important subject in environmental analytical chemistry. To date, several methodologies and technologies have been developed for this purpose ; $^{2-9}$ however, they are not always adequate because the concentration of $\mathrm{Al}$ in samples is usually on the level of $\mu \mathrm{M}$ or sub- $\mu \mathrm{M}$ and the chemical forms of aluminum are quite complex. Owing to the inert nature of $\mathrm{Al}$, a technique combining HPLC and a highly sensitive detection method, such as fluorometry or ICP-MS, would be the most realistic speciation technique, and should usually provide results consistent with thermodynamic predictions. ${ }^{6,8,9}$

In an attempt to directly probe the actual chemical species of $\mathrm{Al}$ present in biological and environmental samples, some effort has been devoted to the use of non-invasive methods that do not disturb the chemical equilibrium of species in solution. ${ }^{27} \mathrm{Al}-$ NMR has been applied to the identification and quantification of particular Al species; $;^{2,10-14}$ however, it lacks sensitivity and selectivity. Recently, Horlick and co-workers investigated the use of electrospray ionization mass spectrometry (ESI-MS) for elemental speciation work, and showed its potential as a technique for probing the solution state of elements directly. ${ }^{15-17}$ ESI-MS has great advantages, such as low detection limit and wide mass spectrometric measurement range, and it is a promising technique for clarifying the chemical forms of dissolved metals and their distribution among various organic and inorganic forms. ${ }^{18,19}$ We also reported the preliminary investigation of the application of ESI-MS to the study of Al

† To whom correspondence should be addressed.

E-mail: hotta@chem-bio.gunma-u.ac.jp speciation, where the ESI-MS spectra of Al-oxalate complexes were obtained at various conditions; the results were compared with those from computer-assisted equilibrium calculations. Under optimum conditions, the mass spectra reflected the solution chemistry of $\mathrm{Al}$ to a considerable extent. A detection limit of $0.06 \mu \mathrm{M}$ was obtained for $\left[\mathrm{Al}(\mathrm{ox})_{2}\right]^{-}(\mathrm{m} / \mathrm{z}, 203)$, where $\mathrm{H}_{2} \mathrm{Ox}$ denotes oxalic acid. ${ }^{20}$

Although $\mathrm{Al}$ is very toxic towards ordinary plants, and is usually characterized by the inhibition of root elongation, some plants, such as hydrangea, buckwheat, and tea, are known as "Al accumulators" and may contain more than 10 times the concentration of $\mathrm{Al}$ in ordinary plants without any injury. Elucidating the internal detoxification mechanism of $\mathrm{Al}$ in $\mathrm{Al}$ accumulators is an important subject in environmental chemistry and agro-chemistry, because Al toxicity limits crop production in acidic soil and the development of Al-tolerating crops will help increase food production worldwide. However, the mechanisms of $\mathrm{Al}$ detoxification in $\mathrm{Al}$ accumulators are still poorly understood. ${ }^{2,21}$ Based on ${ }^{27} \mathrm{Al}-\mathrm{NMR}$ studies, Ma and coworkers recently proposed that $\mathrm{Al}$ is accumulated as a $1: 1$ complex of $\mathrm{Al}$ and citrate in hydrangea leaves ${ }^{22}$ and as a 1:3 complex of $\mathrm{Al}$ and oxalate in buckwheat leaves. ${ }^{23,24}$ They suggest that such chelating reactions of $\mathrm{Al}$ with small organic acids have an important role in the internal detoxification of $\mathrm{Al}$ in $\mathrm{Al}$ accumulators. ${ }^{22,23}$

In this work, ESI-MS was used to identify $\mathrm{Al}$ species in cell sap samples of hydrangea leaves, and to evaluate the applicability of the technique to the speciation analysis of $\mathrm{Al}$ in biological and environmental samples. Although ${ }^{27} \mathrm{Al}-\mathrm{NMR}$ can provide useful information on the kinds of ligands and the coordination state of $\mathrm{Al}$ in solution samples, its application is limited to $\mathrm{Al}$ complexes whose coordination structures are symmetric. Therefore, the identification of $\mathrm{Al}$ complexes solely by ${ }^{27} \mathrm{Al}-\mathrm{NMR}$ is difficult and it is often necessary to confirm or check the results of ${ }^{27} \mathrm{Al}-\mathrm{NMR}$ with an alternative method. ESIMS has great potential to be such a method. 


\section{Experimental}

Reagents

All reagents were obtained commercially in the purest form available and used as received. Water was purified using the Millipore Milli-Q system (Billerica, MA). Typically, stock solutions were prepared by dissolving the reagent in distilled, deionized water.

\section{Sample preparation}

Hydrangea (Hydrangea macrophylla) leaves were collected near our laboratory in summer time. The leaves were washed with distilled water, ground in liquid nitrogen, and placed on filters in centrifuge tubes (Microcentrifuge Filters Ultrafree-CL, molecular weight cutoff 5000, Millipore, Billerica). After 0.5$\mathrm{ml}$ of pure water was added per $1.5 \mathrm{~g}$ of leaf sample, the samples were centrifuged at $6000 \mathrm{rpm}$ for $40 \mathrm{~min}$ at $6^{\circ} \mathrm{C}$ to obtain the cell sap. The $\mathrm{pH}$ of the cell sap solution was $c a$. 5.5. The concentrations of metals, anions, and organic acids in the cell sap were determined using the methods described below.

To purify the $\mathrm{Al}$ complex, $1 \mathrm{ml}$ of freshly prepared cell sap sample was applied to a 10 -mm i.d. $\times 20$-cm-long column packed with Sephadex G-10 (Fluka) and fractionated $\left(\mathrm{ca} .1 \mathrm{~cm}^{3}\right.$ each for every $5 \mathrm{~min}$ ) at room temperature with dilute perchloric acid solution ( $\mathrm{pH} \mathrm{5.5,} \mathrm{the} \mathrm{same} \mathrm{pH}$ as the cell sap) as the eluent. Each fraction (5 min) was 15 times diluted, and was then applied to ICP-AES for Al and ESI-MS.

\section{Apparatus and methods}

ESI-MS measurements. The ESI-MS instrument used in this work was a Shimadzu LC-MS-2010A, Japan. The mass spectrometer was operated in negative ion mode mainly. The instrument conditions were as follows; electrospray voltage, $-3.5 \mathrm{kV}$; Q-array voltage, $-50 \mathrm{~V}$; nebulizer gas $\left(\mathrm{N}_{2}\right)$ flow rate, $1.5 \mathrm{dm}^{3} / \mathrm{min}$; drying gas $\left(\mathrm{N}_{2}\right)$ flow rate, $0.2 \mathrm{~cm}^{3} / \mathrm{min}$. Samples were introduced by a flow injection method with a six-way loop injector whose sample volume was $30 \mathrm{~mm}^{3}$. Distilled water was used as a carrier solution (flow rate, $0.2 \mathrm{~cm}^{3} / \mathrm{min}$ ).

ESI-MS/MS measurements. An Applied Biosystems (CA) API2000 triple quadrupole system was used for ESI-MS/MS measurements to identify the chemical species of the peaks $(\mathrm{m} / \mathrm{z}$ 215). The instrument conditions were as follows: flow rate of the sample solutions, $8.0 \mathrm{~mm}^{3} / \mathrm{min}$; electrospray voltage, -4.5 $\mathrm{kV}$; nebulizer gas $\left(\mathrm{N}_{2}\right), 0.14 \mathrm{MPa}$; curtain gas $\left(\mathrm{N}_{2}\right), 0.14 \mathrm{MPa}$; collision gas, $\mathrm{N}_{2}$ under $1 \times 10^{-5}$ Torr; source temperature, $0^{\circ} \mathrm{C}$; declustering potential, $-30 \mathrm{~V}$; focusing potential, $-200 \mathrm{~V}$; entrance potential, $-10 \mathrm{~V}$; and collision energies were changed from -10 to $-30 \mathrm{~V}$.

Determination of metals. An ICP emission spectrometer (ICPS1000III, Shimadzu Co., Japan) was used to determine metals.

Determination of anions and organic acids. A commercial ion chromatography system with suppressed conductivity detection (separation column: AG4A-SC $4 \mathrm{~mm}$ i.d. $\times 50 \mathrm{~mm}$ long; Dionex Corp., Sunnyvale, CA) was used to detect anions $\left(\mathrm{Cl}^{-}, \mathrm{NO}_{3}^{-}\right.$, $\left.\mathrm{SO}_{4}{ }^{2-}, \mathrm{PO}_{4}{ }^{3-}\right)$, malic acid and oxalic acid in the fractions. The eluent was $1.8 \mathrm{mM}\left(=\mathrm{mmol} / \mathrm{dm}^{3}\right) \mathrm{Na}_{2} \mathrm{CO}_{3}-1.7 \mathrm{mM} \mathrm{NaHCO}$, and the flow rate was $1 \mathrm{~cm}^{3} / \mathrm{min}$. The concentration of citric acid was determined by a standard addition method using ESIMS. Standard samples of $2-6 \mu \mathrm{M}$ citric acid were added into diluted sap solutions (1/5000). ESI-MS instrument conditions were the same as above.

Determination of fluoride ion. The fluoride ion selective electrode method (Combination $\mathrm{F}^{-}$Electrode 9609BN, Orion Research Inc., Beverly, MA) was used for fluoride detection, a)

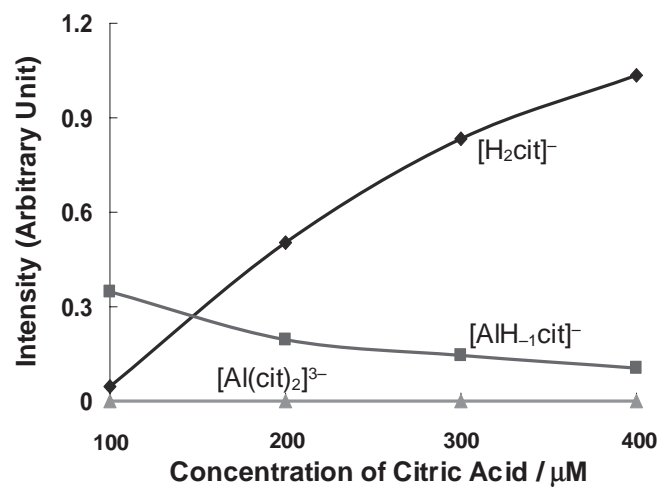

b)



Fig. 1 Comparison of the equilibrium calculation and ESI-MS measurements for Al-citrate solution ( $\mathrm{pH}$ 5). (a) ESI-MS measurements: Al concentration, $100 \mu \mathrm{M}$. The $\mathrm{pH}$ values were adjusted to 5.0 with $\mathrm{NaOH}$. (b) Equilibrium calculation: $\mathrm{Al}$ concentration, $100 \mu \mathrm{M}$.

where TISAB containing $0.01 \mathrm{M}$ CyDTA was added to the sample solution at 1:1. A Horiba F-16 pH meter (Horiba Co., Japan) was used to measure the potential against a standard $\mathrm{Ag} / \mathrm{AgCl}$ electrode.

\section{Equilibrium calculation}

A computer-based thermodynamic equilibrium model (MINEQL+ Ver. 4.5, from Environmental Research Software, Hallowell, ME) was used for equilibrium calculations. The model used the total concentration of each component and the stability constants of species formed at equilibrium to set up a series of mole balance and mass law equations, which were solved to give the equilibrium concentration of each species. Thermodynamic data in Ref. 6 were used for the calculation.

\section{Results and Discussion}

ESI-MS spectra of aluminum-citrate and aluminum-oxalate complexes

As mentioned above, based on their ${ }^{27} \mathrm{Al}-\mathrm{NMR}$ studies, Ma et al. reported that the main $\mathrm{Al}$ species is a 1:1 complex of $\mathrm{Al}$ and citrate in the cell sap of hydrangea leaves and is a 1:3 complex of $\mathrm{Al}$ and oxalate in the cell sap of buckwheat leaves. ${ }^{22,23}$ Therefore, the ESI-MS behavior of these complexes was studied first. Standard solutions containing various concentrations of $\mathrm{Al}$ and citrate were measured using ESI-MS and the results were compared with those of equilibrium calculations. Figures 1a and $1 \mathrm{~b}$ show the results of ESI-MS measurements for $\mathrm{Al}$ and citrate solutions and equilibrium calculations, respectively, where the concentration of citric acid was changed ( $\mathrm{pH}$ 5.0). Equilibrium calculations predicted that the main Al species 

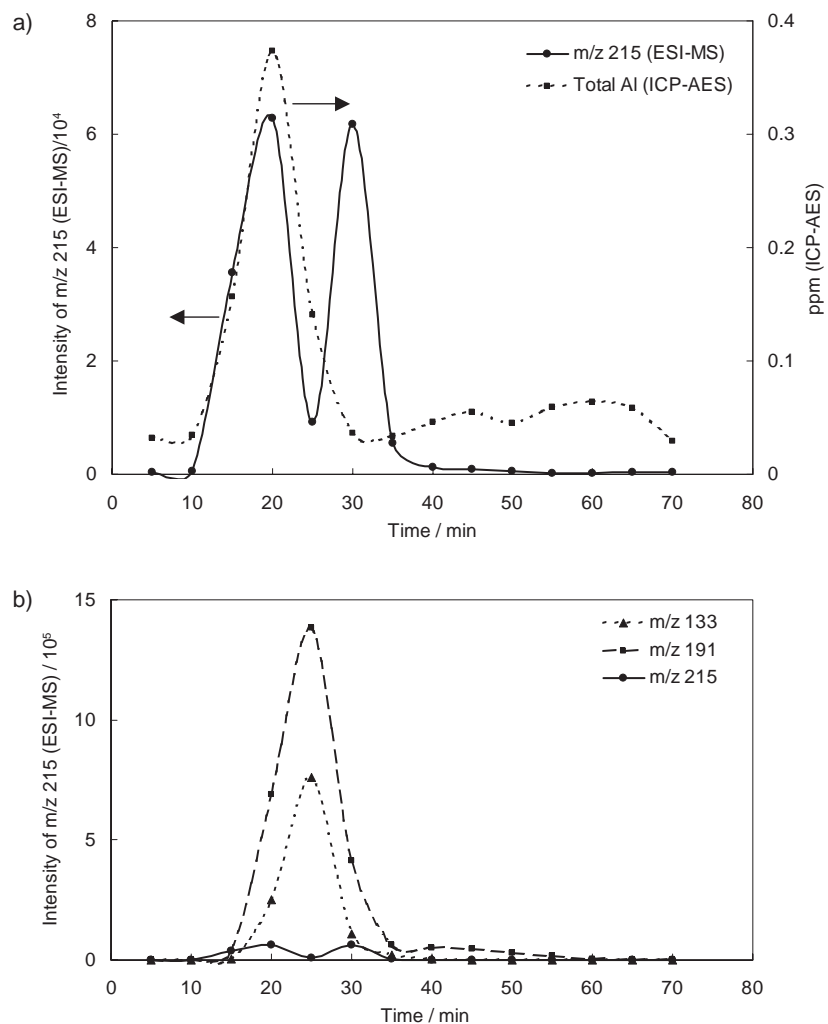

Fig. 2 Off-line mass chromatograms through Sephadex G-10 separation of a sample of hydrangea cell sap. Each fraction $(5 \mathrm{~min})$ was diluted 15 times, then applied to ESI-MS and ICP-AES measurements. (a) Total Al with ICP-AES and intensity at $\mathrm{m} / \mathrm{z} 215$ with ESI-MS, (b) intensities at $\mathrm{m} / z 133$ ([Hmal $\left.]^{-}\right), 191\left(\left[\mathrm{H}_{2} \mathrm{cit}^{-}\right), 215\right.$ (see text) with ESI-MS.

would be $\left[\mathrm{AlH}_{-1} \mathrm{cit}\right]^{-}$, and this species was clearly detected at $\mathrm{m} / \mathrm{z} 215$ in the ESI-MS measurement. Here, $\mathrm{H}_{3}$ cit denotes citric acid; $\mathrm{H}_{-1}$ cit denotes its form where not only three $-\mathrm{COOH}$ groups but also a $-\mathrm{OH}$ group are dissociated. Although the existence of $\left[\mathrm{Al}(\mathrm{cit})_{2}\right]^{3-}$ was also predicted, no peak was observed for this species in the ESI-MS spectrum. This result was in good agreement with that reported earlier. ${ }^{25}$

\section{ESI-MS analysis of cell sap of hydrangea leaves}

The Al concentration found in the original cell sap sample of hydrangea leaf was $0.8 \mathrm{mM}$, which was much higher than those in usual plants. Moreover, the preliminary study using cation exchange HPLC with fluorometric detection revealed that almost all $\mathrm{Al}$ in the cell sap exists as complexed forms. Amounts of other cations were also determined by ICP-AES as $5.2 \mathrm{mM}$ of $\mathrm{Mg}, 7.1 \mathrm{mM}$ of $\mathrm{Ca}$, and $2.5 \mu \mathrm{M}$ of $\mathrm{Fe}$. Anions, $\mathrm{Cl}^{-}$ $19.4 \mathrm{mM}, \mathrm{NO}_{3}^{-} 0.30 \mathrm{mM}, \mathrm{SO}_{4}{ }^{2-} 7.5 \mathrm{mM}, \mathrm{PO}_{4}{ }^{3-} 7.1 \mathrm{mM}$, oxalic acid $0.5 \mathrm{mM}$, and malic acid $1.1 \mathrm{mM}$, were measured by $\mathrm{IC}^{-} \mathrm{F}^{-}$ $(9.2 \mu \mathrm{M})$ was determined by ISE and citric acid $(6.2 \mathrm{mM})$ by ESI-MS. Figure 2 shows the Sephadex G-10 chromatogram of the cell sap sample of hydrangea leaves for total Al. Moreover, the figure includes some peaks in ESI-MS spectra, i.e., $\mathrm{m} / \mathrm{z}, 215$ $\left(\left[\mathrm{AlH}_{-1} \mathrm{cit}^{-}\right), m / z 191\left(\left[\mathrm{H}_{2} \mathrm{cit}^{-}\right)\right.\right.$, and $m / z 133\left([\mathrm{Hmal}]^{-}\right)$, where $\mathrm{H}_{2}$ mal denote malic acid. As is shown in the result of ICP-AES (dotted line in Fig. 2a), the Al showed the peak at the fraction 20 min. Thus, its ESI-MS spectrum is as shown in Fig. 3. In the figure, $m / z$ 215, which is ascribed to $\left[\mathrm{AlH}_{-1} \mathrm{cit}^{-}\right.$was identified; the other expected complexes of $\left[\mathrm{Al}(\mathrm{Ox})_{2}\right]^{-}(\mathrm{m} / \mathrm{z}, 203)$, $\left[\mathrm{Al}\left(\mathrm{H}_{-1} \mathrm{cit}\right)\left(\mathrm{H}_{3} \mathrm{cit}\right)\right]^{-}(407)$ and $\left[\mathrm{Al}\left(\mathrm{H}_{-1} \mathrm{mal}\right)\left(\mathrm{H}_{2} \mathrm{mal}\right)\right]^{-}(291)$, could

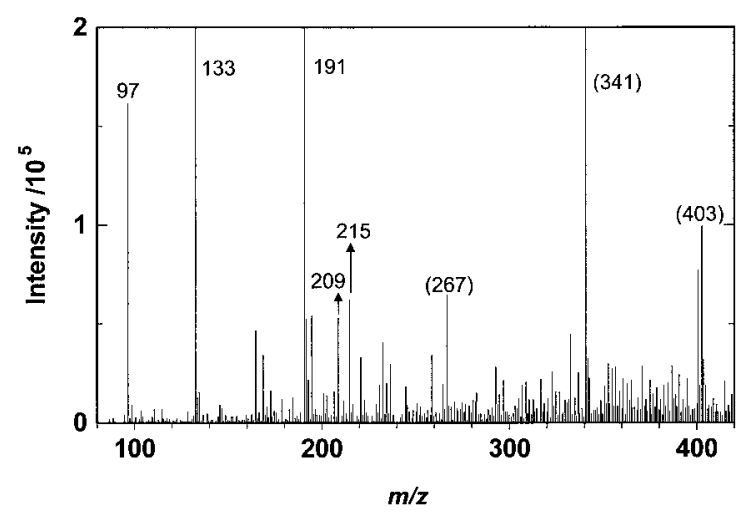

Fig. 3 Mass spectrum of 20 min fraction with ESI-MS.

not be detected in this study. Other peaks of $\mathrm{m} / \mathrm{z}, 267,341$, and 403 could not be assigned (these peaks were not detected in the model solution including $\mathrm{Al}$ and citric acid). In particular, as $\mathrm{m} / \mathrm{z} 215$ is the main peak of the model solution of $\mathrm{Al}$ and citrate as discussed above, the peak of $\mathrm{m} / \mathrm{z} 215$ should be due to [AlH ${ }_{-1}$ cit] $^{-}$. As shown in Fig. 2, however, two peaks for $m / z, 215$ were observed at the 20 and $30 \mathrm{~min}$ fractions, respectively. Thus, further studies were necessary to identify the chemical species of these peaks. We applied the ESI-MS/MS method for this purpose. The ESI-MS/MS spectra of $\mathrm{m} / \mathrm{z} 215$ for the model solution of $\mathrm{Al}$ and citrate were obtained; these were compared with those of the 20 and 30 min fractions. Figure 4a shows the MS/MS spectrum of $\mathrm{m} / \mathrm{z}, 215$ for the model solution, where two relatively strong peaks of the fragment ions of $\mathrm{m} / \mathrm{z}, 111$ and 172 were observed. Though these fragments were not identified, this spectrum showed good agreement with the spectrum for the fraction of $20 \mathrm{~min}$ (Fig. 4b), while the spectrum for model solution was very different from that for the fraction of $30 \mathrm{~min}$ (Fig. 4c). Therefore, it was concluded that the peak of $\mathrm{m} / \mathrm{z} 215$ at the fraction of 20 min can clearly be ascribed to [AlH $\left.\mathrm{Alit}_{-1}\right]^{-}$.

\section{Al species in cell saps of hydrangea}

As mentioned above, we found a 1:1 complex of $\mathrm{Al}$ and citrate, $\left[\mathrm{AlH}_{-1} \mathrm{cit}\right]^{-}$at the fraction of $20 \mathrm{~min}$ of the cell sap of hydrangea leaves, which was also the peak fraction of total $\mathrm{Al}$ as shown in Fig. 2. This result is consistent with the conclusion of NMR studies by Ma et al., ${ }^{22}$ i.e., the main $\mathrm{Al}$ species in the cell sap of hydrangea leaves is the 1:1 complex of $\mathrm{Al}$ and citrate. Although Ma et al. used hydroponically cultured hydrangea plants with Hoagland solution with the elevated level of $\mathrm{Al},{ }^{22}$ the Al level of their cell sap ( $c a .2 \mathrm{mM}$ ) was only slightly higher than that of our samples ( $c a .0 .8 \mathrm{mM}$ ) which was from natural hydrangea plants. Thus, the nature of the hydrangea samples used in Ma's group and us may not be so greatly different.

Electrospray ionization mass spectrometry (ESI-MS) in negative ion mode was thus successfully applied to identify Al species in Al-accumulating plant, hydrangea. In hydrangea leaves, the 1:1 Al-citrate complex was mainly found as $\left[\mathrm{AlH}_{-1} \mathrm{cit}^{-}(\mathrm{m} / \mathrm{z}, 215)\right.$. As only stable $\mathrm{Al}$ species with a single negative charge in solution could be detected with high sensitivity using ESI-MS in this study, the concomitant use of equilibrium calculations will be useful for identifying all $\mathrm{Al}$ species. Moreover, since ESI-MS is much more sensitive than ${ }^{27} \mathrm{Al}-\mathrm{NMR}$, it could be applied to study $\mathrm{Al}$ species in both $\mathrm{Al}$ accumulators and ordinary plants. To extend the applicability of ESI-MS to speciation analysis for other trace elements, fundamental studies are still necessary to understand the 
a)

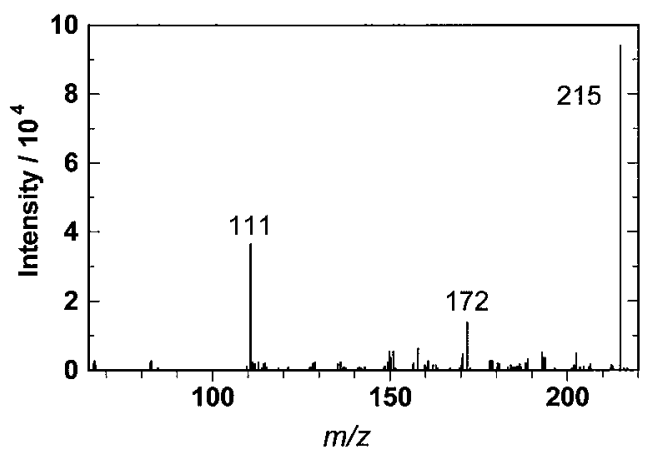

b)

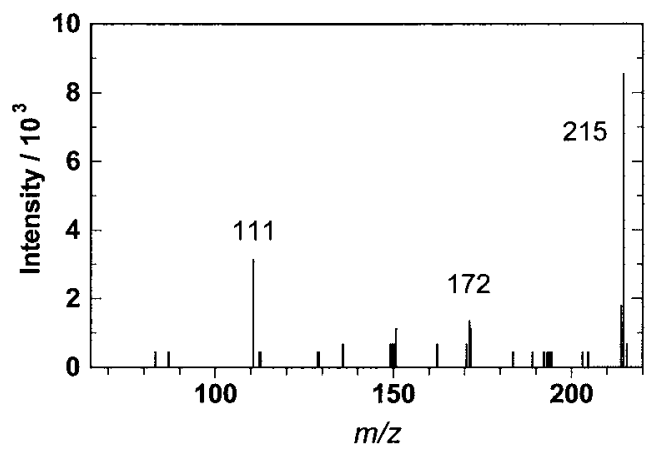

c)

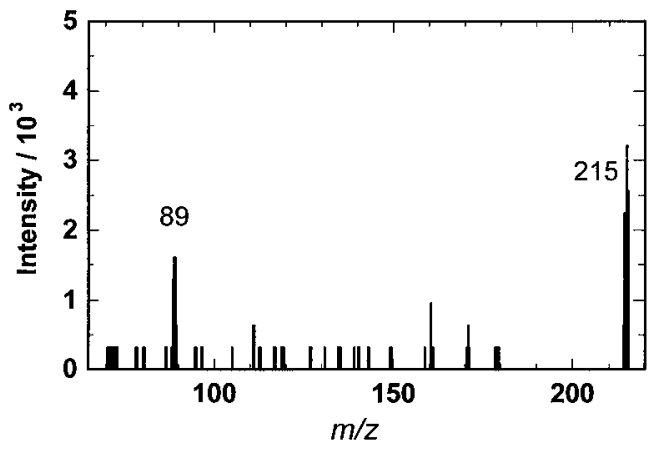

Fig. 4 MS/MS spectrum of (a) model solution for $\mathrm{m} / \mathrm{z}$ 215, (b) fraction of $20 \mathrm{~min}$, and (c) fraction of $30 \mathrm{~min}$. The model solution contains $0.5 \mathrm{mM}$ of $\mathrm{Al}$ and $5 \mathrm{mM}$ of citric acid at $\mathrm{pH}$. Collision energy: $-20 \mathrm{~V}$.

ionization process of metal species in solutions in ESI-MS and how ESI-MS spectra reflect the solution equilibria. Moreover, the MS/MS technique greatly improves the identification power of the method.

\section{Acknowledgements}

We thank Prof. Yoshimura of the University of Tokyo, Japan, for his valuable discussion on ${ }^{27} \mathrm{Al}-\mathrm{NMR}$, and Prof. Tobita of Gunma University, for his valuable discussion on ESI-MS/MS. This study was supported in part by a Grant-in-Aid for Scientific Research (B-14350441) from the Japan Society for the Promotion of Science.

\section{References}

1. P. G. C. Campbell, M. Bisson, R. Boagie, A. Tessier, and J. P. Villeneuve, Anal. Chem., 1983, 55, 2246.

2. K. Tsunoda, Biomed. Res. Trace Elements, 2005, 16, 276.

3. J. I. G. Alonso, A. L. Garcia, A. Sanz-Medel, E. B. Gonzalez, L. Ebdon, and P. Jones, Anal. Chim. Acta, 1989, 225, 339.

4. P. M. Bertsch and M. A. Anderson, Anal. Chem., 1989, 61, 535.

5. Y. Lu, C. L. Chakrabarti, M. H. Back, D. C. Gregoire, W. H. Schroeder, A. G. Szabo, and L. Bramall, Anal. Chim. Acta, 1994, 288, 131.

6. K. Tsunoda, T. Yagasaki, S. Aizawa, H. Akaiwa, and K. Satake, Anal. Sci., 1997, 13, 757.

7. B. Fairman, A. Sanz-Medel, P. Jones, and E. H. Evans, Analyst, 1998, 123, 699.

8. K. Tsunoda, T. Umemura, K. Ohshima, S. Aizawa, E. Yoshimura, and K. Satake, Water, Air, Soil Pollut., 2001, $130,1589$.

9. T. Umemura, Y. Usami, S. Aizawa, K. Tsunoda, and K. Satake, Sci. Total Environ., 2003, 317, 149.

10. F. Thomas, A. Masion, J. Y. Bottero, J. Rouiller, F. Montigny, and F. Genevrier, Environ. Sci. Technol., 1993, 27, 2511.

11. G. L. Kerven, P. L. Larsen, L. C. Bell, and D. G. Edwards, Plant Soil, 1995, 171, 35.

12. P. A. Jordan, N. J. Clayden, S. L. Heath, G. R. Moore, A. K. Powell, and A. Tapparo, Coord. Chem. Rev., 1996, 149, 281.

13. B. C. Faust, W. B. Labiosa, K. D. Dai, J. S. Macfall, B. A. Browne, A. A. Ribeiro, and D. D. Richter, Geochim. Cosmochim. Acta, 1995, 59, 2651.

14. E. Yoshimura, M. Akashi, T. Umemura, and K. Tsunoda, Anal. Sci., 2004, 20, 373.

15. G. R. Agnes and G. Horlick, Appl. Spectrosc., 1992, 46, 401.

16. G. R. Agnes, I. I. Stewart, and G. Horlick, Appl. Spectrosc., 1994, 48, 1347.

17. I. I. Stewart and G. Horlick, J. Anal. At. Spectrom., 1996, 11,1203 .

18. S. Mollah, A. D. Pris, S. K. Johnson, A. B. Gwizdala III, and R. S. Houk, Anal. Chem., 2000, 72, 985.

19. A. R. S. Ross, M. G. Ikonomou, J. A. Jeffrey-Thompson, and K. J. Orians, Anal. Chem., 1998, 70, 2225.

20. T. Umemura, K. Asaka, K. Sekizawa, T. Odake, K. Tsunoda, K. Satake, Q. Wang, and B. Huang, Anal. Sci., 2001, 17, i49.

21. J. F. Ma, Plant Cell Physiol., 2000, 41, 383.

22. J. F. Ma, S. Hiradate, K. Nomoto, T. Iwashita, and H. Matsumoto, Plant Physiol., 1997, 113, 1033.

23. J. F. Ma, S. J. Zheng, H. Matsumoto, and S. Hiradate, Nature, 1997, 390, 569.

24. R. Shen, T. Iwashita, and J. F. Ma, J. Exp. Bot., 2004, 55, 131.

25. V. B. D. Marco, G. G. Bombi, M. Ronaldo, and P. Traldi, Rapid Commun. Mass Spectrom., 2007, 21, 3825. 